\section{Disinfection and Outcome of Root Canal Treatment Using Single-File Or Multifile Systems and $\mathrm{Ca}(\mathrm{OH})_{2}$ Medication}

\author{
Mônica A. S. Neves ${ }^{10}$, José C. Provenzano ${ }^{1,2}{ }^{\circledR}$, Simone C. L. Fonseca ${ }^{2}$ \\ Renata C. V. Rodrigues ${ }^{3}$, Lucio S. Gonçalves ${ }^{1}{ }^{(\mathbb{D})}$, José F. Siqueira Jr ${ }^{2}$, Isabela \\ N. Rôças ${ }^{2}$ (i)
}

\author{
'Department of Endodontics, School \\ of Dentistry, Universidade Estácio \\ de Sá, Rio de Janeiro, RJ, Brazil \\ ${ }^{2}$ Department of Endodontics, School \\ of Dentistry, UNIG - Universidade \\ lguaçu, Nova lguaçu, RJ, Brazil \\ ${ }^{3}$ Department of Endodontics, School \\ of Dentistry, UVA - Universidade \\ Veiga de Almeida University, \\ Rio de Janeiro, RJ, Brazil
}

Correspondence: José Claudio Provenzano, Avenida Alfredo Baltazar da Silveira, 580, 22790-710 Rio de Janeiro, RJ, Brasil. Tel: +55-21- 40036767. e-mail: odontojcp@gmail.com

Key Words: apical periodontitis, periapical healing, singlefile preparation, treatment outcome, calcium hydroxide.

\begin{abstract}
This clinical study reports on the antibacterial effects and outcome of endodontic treatment using either a single-file or a multifile system, associated with calcium hydroxide interappointment medication. The root canals of single-rooted teeth with apical periodontitis were treated by using either Reciproc or BioRaCe instrument systems, 2.5\% $\mathrm{NaOCl}$ irrigation, and calcium hydroxide medication. Bacteriological samples taken before preparation and immediately before obturation were evaluated for total bacterial counts by quantitative real-time polymerase chain reaction (qPCR). Patients were followed up and the treatment outcome was assessed by clinical and radiographic criteria. Decreasing lesions were classified as success in a lenient criterion or failure in a rigid one. Bacteria were detected in all initial samples (47 cases) and were significantly reduced after treatment in both groups $(p<0.001)$. In the Reciproc and BioRaCe groups, 7/25 $(28 \%)$ and 11/22 $(50 \%)$ root canals yielded negative qPCR results before obturation, respectively ( $p>0.05)$. Quantitative bacterial reduction was similar between groups $(p>0.05)$. The success rate in the BioRaCe group was $95.5 \%$ and $77 \%$ in the loose and rigid criterion, respectively. In the Reciproc group, corresponding figures were $88 \%$ and $76 \%$. Differences in outcome were not significant $(p>0.05)$. No diseased case showed negative $q P C R$ results for bacteria. A difference of $>1$ Log 10 counts was observed between healed and diseased cases. Root canal treatments of teeth with apical periodontitis using a single-file or a multifile system for preparation, associated with $\mathrm{NaOCl}$ irrigation and calcium hydroxide interappointment medication, showed similar antibacterial effectiveness and success rate.
\end{abstract}

\section{Introduction}

Proper intracanal infection control is of paramount importance for the successful outcome of the endodontic treatment of teeth with apical periodontitis (1). During antimicrobial endodontic treatment procedures, instruments and irrigants are used to eliminate bacteria, their products and antigens, as well as substrate (necrotic pulp tissue) from the main canal and in its immediate vicinity, creating favorable conditions for restoration of the periradicular tissue health (2).

Traditionally, chemomechanical preparation has been performed by using a series of instruments of progressively larger sizes. Over the last decade, following the proposal of preparing canals with a single instrument (3), several novel single-file systems have been made commercially available. One of them - Reciproc (VDW, Munich, Germany) - is currently one of the most used and tested single-file systems. Several studies comparing the Reciproc single-file system with different multifile systems have shown similar results in terms of intracanal cleaning and disinfection (4-12). However, no study has so far evaluated the outcome of the endodontic treatment of teeth with apical periodontitis using single-file preparation and compared with multifile systems.

The ideal endpoint for comparisons of the efficacy of endodontic procedures is the treatment outcome. The best treatment protocols are those that predictably result in normal clinical conditions and healthy periradicular tissues after an appropriate follow-up period. Assessing the endodontic treatment outcome is somewhat problematic because a reliable evaluation can only be done after at least one year follow-up examination (13). Antibacterial studies have been regarded as surrogate end-points for treatment outcome, because attainment of negative root canal cultures before filling projects a good outcome (14). Therefore, one can anticipate better long-term outcomes for endodontic techniques and protocols that can predictably control endodontic infections and ideally render canals free of bacteria. All previous culture studies were qualitative (presence/absence) in nature, i.e., none of them evaluated the relationship between bacterial counts and the outcome. This can be a serious drawback, because a tooth containing for example 100,000 residual bacterial cells have more theoretical chances to fail than a tooth that harbors only 100 residual cells, but both would be classified as positive 
in a qualitative analysis. Molecular methods can be more informative than culture because they are more sensitive (they can detect fewer cells), and include culture-difficult and as-yet-uncultivated bacteria in the analysis (15). A recent study revealed that the treatment outcome was significantly improved when the canal was negative for bacterial presence or had less than $10^{3}$ bacterial cells at the time of filling as detected by a molecular microbiology method (14).

This clinical study reported on the antibacterial effects and outcome of endodontic treatments based on chemomechanical preparation with either a singlefile or a multifile system, followed by calcium hydroxide interappointment medication. Total bacterial counts were evaluated before and after treatment using a cultureindependent molecular microbiology assay, and the cases were followed up clinically and radiographically for more than one year.

\section{Material and Methods}

\section{Subject Population}

Eighty patients attending the clinic at the Department of Endodontics, for initial root canal treatment participated in this study. Sixty of these patients had been included in a previous study evaluating the intracanal bacterial reduction immediately after preparation with Reciproc and BioRaCe (11). Inclusion criteria were: single-rooted teeth with a single canal, asymptomatic teeth with necrotic pulps and periapical radiolucency; teeth with completely formed root apices; and patients reporting no significant systemic condition. Exclusion criteria were: teeth with extensive crown destruction by caries or previous restoration; previous endodontic intervention; presence of preoperative symptoms; patients who have taken systemic antibiotics over the last 3 months; and patients with periodontal pockets $>4$ $\mathrm{mm}$. The protocol for the present antibacterial and outcome study was approved by the Institutional Ethics Committee (protocol approval \#1.928.654).

\section{Sample Taking and Treatment Procedures}

Root canal samples were taken before (S1) and after (S2) root canal preparation using paper points as described previously (11). Preparation procedures for the 20 new cases were the same as reported in the previous study (11). Teeth were randomly distributed into two groups of 40 each and the canals were prepared by using either BioRaCe (FKG Dentaire, La Chaux-de-Fonds, Switzerland) or Reciproc (VDW) instruments. Randomization was done by using drawing of lots from an opaque container for equal proportion allocation between groups. Drawing was conducted by the dental assistant and informed to the operator immediately after S1 taking and before instrumentation. Two operators, who are highly experienced endodontists, were randomly assigned to the techniques and performed all the treatments.

The working length (WL) was established $1 \mathrm{~mm}$ short of the apical foramen and the foramen patency was checked with a small size hand file during and after preparation. In the BioRaCe group, the master apical file ranged from BR5 (40/.04) to BR6 (50/.04). In the Reciproc group, apical preparation was done using R40 or R50 as the single instrument. Irrigation with $2.5 \% \mathrm{NaOCl}$ and checking of the apical foramen patency was performed after each file size in the BioRaCe group and after each cycle of 3 in-and-out pecking motions in the Reciproc group. A 30-gauge NaviTip needle (Ultradent, South Jordan, UT, USA) placed $3 \mathrm{~mm}$ short of the WL was used for irrigant delivery.

Smear layer was removed by irrigation with $5 \mathrm{~mL}$ 17\% EDTA and $5 \mathrm{~mL} 2.5 \% \mathrm{NaOCl}$. The same total volume of $\mathrm{NaOCl}$ was used for preparation with both systems $(15 \mathrm{~mL})$. A post-preparation bacteriological sample (S2) was taken (11) and the canal was dried using sterile paper points and medicated with a calcium hydroxide paste in camphorated paramonochlorophenol and glycerin. The paste was applied to the root canal up to the WL by using a lentulo spiral operated in continuous rotation. A radiograph was taken to check for appropriate canal filling with the paste, the pulp chamber was cleaned from calcium hydroxide paste residues, and a temporary cement (Coltosol, ColtèneWhaledent, Altstätten, Switzerland) was placed. The patient was scheduled to 7 to 10 days later for obturation.

In the second appointment, the patient was anesthetized, the tooth crown was cleaned, rubber dam was placed, and the operative field was disinfected by the sequential use of $6 \%$ hydrogen peroxide and $2.5 \% \mathrm{NaOCl}$ before and after removal of the temporary cement the same way as for the previous session (11). $\mathrm{NaOCl}$ was neutralized with sodium thiosulfate, and a second-visit sterility control sample was taken. Sterility controls from the first and second visits were subjected to the same molecular microbiology assay used to evaluate the intracanal samples. The calcium hydroxide paste was removed from the canal by irrigation with 5 $\mathrm{mL}$ sterile saline solution and recapitulation with the last instrument size used for apical preparation at the WL. Another bacteriological sample (S3) was taken from the canal the same way as for S1 and S2. Canals were filled by using the lateral compaction technique with gutta-percha and Sealer 26 cement (Dentsply, Petrópolis, RJ, Brazil). A temporary coronal restoration with light-cured composite resin or glass ionomer cement was placed and the tooth permanently restored in less than 1 month.

\section{DNA Extraction and qPCR Analysis}

DNA from clinical samples was extracted by using the OIAamp DNA Mini Kit (Qiagen, Valencia, CA, USA). The total bacterial counts were evaluated before and after treatment 
procedures by using universal $16 \mathrm{~S}$ rRNA gene-based primers $(16)$ in a qPCR assay as described in previous studies $(11,17)$.

\section{Outcome Evaluation}

Patients were followed up to assess the periradicular tissue healing response after treatment with the 2 instrumentation techniques. They were contacted by telephone calls or e-mails every 6 months. Only cases with more than 1-year radiographic follow-up were included, except for cases that developed clinical signs or symptoms earlier. Radiographs were taken using a film holder, processed using the same protocol, and then scanned for incorporation in Power Point files. Analyses of the preoperative, postoperative and follow-up radiographs were carried out on the computer screen, in a darkened room, independently by 2 blinded evaluators, who are experienced endodontists. Scores were attributed to the radiographs according to the Periapical Index (PAI) (18). When disagreement occurred, a 3rd endodontist was consulted. The 3 observers were calibrated against a set of 100 reference radiographs (kindly supplied by Dag Orstavik, University of Oslo). Cases categorized in the follow-up radiographs as PAI score 1 and 2 were regarded as healed, while cases receiving scores 3 to 5 were regarded as diseased if the score was unchanged or increased when compared with radiographs taken at the time of treatment. Those cases showing a decrease in the PAI score were classified as healing.

According to both radiographic (PAI criterion) and clinical evaluation, the outcome was dichotomized using rigid or loose criteria:

- Rigid criterion: success comprised teeth categorized as healed in PAI radiographic evaluation and showing no clinical signs and symptoms of disease. Healing and diseased cases were considered as failure.

- Loose criterion: success was defined for cases categorized as healed or healing in PAI and showing no clinical signs and symptoms. In PAI analysis, only diseased teeth were considered as failure.

Variables that might influence the treatment outcome were evaluated for their distribution between groups and their effects on treatment outcome, including: size of the apical periodontitis lesion (small: $<5 \mathrm{~mm}$; large: $>5 \mathrm{~mm}$ ), patient age and gender, and presence of a sinus tract.

\section{Statistical Analysis}

Data normality was verified by means of the Kolmogorov-Smirnov and Shapiro-Wilk tests, and graphical analyses. Quantitative total bacteria data from qPCR were evaluated for intragroup comparisons between S1 and S3 samples with the Wilcoxon matched pairs test. The Poisson regression model was used for intergroup comparisons of total bacterial counts in S3 by adjusting for bacterial counts in S1 as described elsewhere (19). Data for bacterial presence/absence in S3 were compared between groups by using the Fisher's exact test. Data for S2 were evaluated in a previous study (11), but re-evaluated here by adding the new cases. As for outcome analysis, the Kappa coefficient was used to analyze the agreement among examiners. Correlation analyses were performed between two continuous variables (Pearson correlation coefficient); between dichotomic and continuous variables (point biserial correlation coefficient); and between two dichotomous variables (phi correlation coefficient). The influence of the treatment protocol as well as the other variables on the outcome was also assessed by means of the Mann-Whitney U test, the chi-square test with Yates' correction, and the Fisher's exact test. The significance level established for all analyses was 5\%. The Statistical Package for Social Science (SPSS, version 21.0, IBM, Armonk, NY, USA) and the STATISTICA v8.0 software (StatSoft, Tulsa, OK, USA) were used to perform all analyses.

\section{Results}

Of the 80 individuals included in the study, 49 returned for follow-up examination, but 2 had to be excluded because of positive results in the sterility control samples for qPCR analysis. Thus, both microbiological and outcome analyses involved 47 individuals ( 25 from the Reciproc group and 22 from the BioRaCe group). Reasons for patients not returning were because they moved or did not respond to telephone/e-mail calls.

All evaluated teeth showed adequate restorations at the time of follow-up. Four cases showed postoperative symptoms after the 1st visit, all of them belonging to the Reciproc group. Age of the 47 patients ranged from 12 to 70 years (mean, 37.5 years). The mean ages for the patients treated with BioRaCe and Reciproc were 36 and 38.8 years, respectively. As for the gender, the BioRaCe group had 11 females and 11 males, while in the Reciproc group 17 were females and 8 were males. A sinus tract occurred in 2 cases from the BioRaCe group and 1 from the Reciproc. Four lesions from the BioRaCe group and 2 from the Reciproc group were categorized as large $(>5 \mathrm{~mm})$. Neither of these variables were significantly different between groups nor influenced the treatment outcome ( $p>0.05$ ).

\section{Antibacterial Evaluation}

Bacteria were detected in all $47 \mathrm{~S} 1$ samples as revealed by qPCR with universal $16 \mathrm{~S}$ rRNA gene-based primers. After chemomechanical preparation with Reciproc or BioRaCe, followed by intracanal medication with calcium hydroxide, $7 / 25(28 \%)$ and $11 / 22(50 \%)$ root canals were negative for bacteria, respectively. This difference was not statistically 
significant ( $p>0.05)$.

Quantitative data for total bacteria are summarized in Table 1. In the BioRaCe group, a median number of 1.69 $\times 10^{5}$ bacterial cell equivalents occurred in S1 samples and was substantially reduced in S3 to a median of 6.05 $\times 10^{1}$ cells $(p<0.001)$. In the Reciproc group, a median of $6.89 \times 10^{5}$ bacterial cells was observed in S1, significantly decreasing in $\mathrm{S} 3$ to a median of $1.55 \times 10^{2}(\mathrm{p}<0.001)$. Comparison between groups for S3 data showed no significant difference between the 2 protocols $(p>0.05)$. The same was observed for $\mathrm{S} 2(\mathrm{p}>0.05)$ (data not shown).

\section{Outcome Evaluation}

The follow-up evaluation period ranged from 12 to 34 months, except for 1 individual from the Reciproc group who presented with emergent sinus tract and symptoms after 4 months and was classified as diseased (failure) because of clinical symptoms (PAl score in this case was 5 in preoperative, postoperative and follow-up radiographs). Mean (median) for the follow-up period was 20.5 (18.5) months for BioRaCe and 17.4 (18) months for Reciproc ( $p>0.05)$.

In the BioRaCe group, 17 cases were healed and 4 cases exhibited reduced lesions (healing). Therefore, the success rate was 95.5\% (21/22 cases) when the loose criterion was used. Using the rigid criterion, the corresponding figure was 77\% (17/22 cases). In the Reciproc group, 19 cases showed complete healing and 3 cases were healing. The success rate was $88 \%$ (22/25 cases) in the loose criterion and 76\% (19/25 cases) in the rigid criterion. Differences within each criterion were not statistically significant between groups ( $p>0.05)$. The mean (median) PAl score decreased from 4.1 (4) to 1.8 (1) in the BioRaCe group, and from 3.7 (4) to 2 (2) in the Reciproc group. There were no significant differences between groups either ( $p>0.05$ ) (Fig. 1).

Of the 18 cases showing negative bacterial results, 14 were healed and the other 4 (2 from each group) were healing. The median bacterial counts of the diseased cases was $2.65 \times 10^{3}$ bacterial cell equivalents, while in the healed cases it was $1.30 \times 10^{2}$ cells, i.e., a difference of $1.3 \log _{10}$ counts. However, because only 4 teeth were diseased, it was not possible to statistically compare the bacterial counts at the time of obturation between healed/ healing and failed cases.

\section{Discussion}

This clinical study was intended to report on the antibacterial effectiveness and the outcome of the endodontic treatment of teeth with apical periodontitis using two treatment protocols. The only difference between the test protocols was that preparation was carried out with either a single-file or a multifile system. In both groups, irrigation was performed with the same volume of $2.5 \% \mathrm{NaOCl}$, smear layer was removed, and intracanal medication with a calcium hydroxide paste was placed. Antibacterial effects were analyzed by using a highly sensitive molecular microbiology method, which showed no significant differences between groups. Patients were followed-up for more than 1 year and a satisfactory radiographic/clinical success rate was observed, with no significant difference between the two protocols either.

This study is a follow-up of the cases treated in a previous one (11) with inclusion of more cases. In that previous study, samples taken immediately after instrumentation revealed no significant difference between single-file and multifile systems. Similar findings were also observed in the present study after adding more cases and are in agreement with many other in vivo and ex vivo studies (4-12). In the present study, post-treatment samples taken after intracanal medication were used for evaluation, because it was our purpose to evaluate the bacterial counts at the time of obturation. This is one of the factors that recognizably may project the treatment outcome (14). Studies have shown that enlargement of the apical canal significantly increases bacterial elimination (20-22). Although two different automated systems were evaluated in the present study, relatively large preparations to similar instrument sizes were used, independent of the

Table 1. Bacterial counts in root canal samples of teeth with apical periodontitis taken before (S1) and after treatment using preparation a reciprocating single instrument or a continuously rotating multi-instrument series followed by calcium hydroxide medication (S3). Data from quantitative $\mathrm{qPCR}$ analysis

\begin{tabular}{|c|c|c|c|c|c|c|c|c|}
\hline Groups & $\begin{array}{c}\text { S1 } \\
\text { Mean }\end{array}$ & Median & Range & $\begin{array}{c}\text { S3 } \\
\text { Mean }\end{array}$ & Median & Range & $\begin{array}{l}\text { Mean } \% \\
\text { S1 to S3 } \\
\text { reduction }\end{array}$ & $\begin{array}{c}\text { Cases negative } \\
\text { for bacteria } \\
\text { in S3 }(\%)\end{array}$ \\
\hline $\begin{array}{l}\text { BioRaCe } \\
(n=22)\end{array}$ & $9.75 \mathrm{E}+05$ & $1.69 \mathrm{E}+05$ & $\begin{array}{c}9.53 \mathrm{E}+02- \\
1.02 \mathrm{E}+07\end{array}$ & $1.13 \mathrm{E}+04$ & $6.05 \mathrm{E}+01$ & $\begin{array}{c}0- \\
9.30 \mathrm{E}+04\end{array}$ & $97.3^{*}$ & $11(50 \%)^{* *}$ \\
\hline $\begin{array}{l}\text { Reciproc } \\
(n=25)\end{array}$ & $1.20 \mathrm{E}+07$ & $6.89 \mathrm{E}+05$ & $\begin{array}{c}3.26 \mathrm{E}+02- \\
8.06 \mathrm{E}+07\end{array}$ & $4.11 \mathrm{E}+04$ & $1.55 \mathrm{E}+02$ & $\begin{array}{c}0 \\
-2.55 \mathrm{E}+05\end{array}$ & $96.6^{*}$ & $7(28 \%)^{* *}$ \\
\hline
\end{tabular}

*Intragroup reduction was statistically significant $(\mathrm{p}<0.001) .{ }^{* *}$ Comparison between groups was not significant $(\mathrm{p}>0.05)$. 
system used. This fact certainly influenced the results.

The possibility also exists that the intracanal medication with calcium hydroxide may have leveled the antibacterial results and have been responsible for the similar bacterial reduction levels and treatment outcome. However, it is important to emphasize that numerous previous studies have found no significant antibacterial differences between single-file and multifile systems, especially when the same irrigant volumes were used $(4-8,11,12)$. The same was observed for this study when comparing S2 samples. Therefore, considering that microbiological results can be used as surrogate end-point outcome, the similar outcomes of apical periodontitis healing were expected. At least, based on the present findings, one can state that the treatment outcome of teeth treated with single-file or multifile systems is similar when using the same $\mathrm{NaOCl}$ volume of irrigation and interappointment medication with calcium hydroxide. Further studies isolating these variables should evaluate if there are differences between the 2 approaches after a single-visit treatment.

No significant difference in outcome was observed between groups, either using a rigid or a lenient criterion. Overall, 4 of 47 teeth (8.5\%) showed persistent disease classified as failures. Seven other teeth (15\%) had lesions that were decreasing in size. Most cases with decreased lesions are expected to completely heal in $4-5$ years (23), but in some cases the lesion size may stabilize and do not completely heal whatsoever. This may happen because the lesion size is directly proportional to the number of bacterial cells and species in the root canal (24); thus, if the intracanal bacterial load is not reduced to the point of being compatible with complete healing, the lesion may decrease in size but not disappear. This is the reason why we used two criteria to classify healing lesions - one optimistic (loose) and the other pessimistic (rigid).

The follow-up evaluation period was more than 1 year, except for one symptomatic case from the Reciproc with a sinus tract that was categorized as diseased after 4 months and was subjected to retreatment. This case reduced the

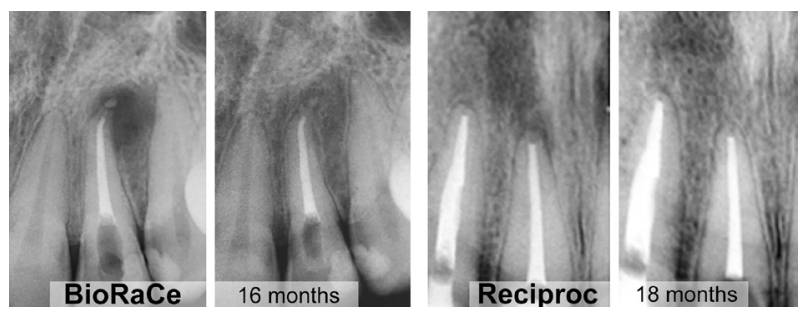

Figure 1. Postoperative and follow-up radiographs from representative cases treated with a multifile (BioRaCe) and a single-file system (Reciproc). The tooth treated with Reciproc and included in the study was the central incisor. mean follow-up time of the Reciproc group, but the medians were very close (18.5 months for BioRaCe and 18 months for Reciproc), and no statistically significant difference was observed. It has been observed that the peak incidence of healing of apical periodontitis occurs at 1-year followup, and the majority of cases will be completely healed after 1-2 years $(13,25)$. A limitation of the present study was the recall rate, which comprised $59 \%$ of the patients available for outcome analysis. Despite numerous attempts to contact the other patients, they could not be reached either because they moved or did not answer the telephone or e-mail calls. Thus, their absence could not be associated with the outcome. Although the difference in success rate between the two techniques was too small ( $1 \%$ when using the rigid criterion), future studies with a larger sample size and a longer follow-up period should be conducted to confirm the present outcome findings.

No failure case showed negative results for bacteria. However, the number of failed cases was too small to permit any comparisons with healed cases as for the number of residual bacterial cells at the time of obturation or the number of cases positive for bacteria (100\% in diseased and $61 \%$ in healed cases). Even so, healed cases showed 1 Log 10 bacterial cell counts less than diseased cases. This reinforces the concept that maximum bacterial reduction is of utmost relevance in the treatment of teeth with apical periodontitis. Four of the 7 healing cases showed negative results for bacteria, suggesting that these cases would inevitably heal completely had the follow-up time been extended. Further studies using a higher number of cases are required to evaluate the correlation of bacterial reduction as determined by sensitive molecular methods and the treatment outcome.

Root canal treatments of teeth with apical periodontitis using a single-file and a multifile system for preparation, associated with $\mathrm{NaOCl}$ irrigation and calcium hydroxide interappointment medication, showed similar antibacterial effectiveness and success rate.

\section{Resumo}

Este estudo clínico relata os efeitos antibacterianos e o resultado de tratamentos endodônticos usando um sistema de instrumentação de instrumento único ou de múltiplos instrumentos, associado à medicação intracanal com hidróxido de cálcio. Os canais radiculares de 80 dentes unirradiculares com lesão perirradicular foram tratados com os sistemas Reciproc ou BioRaCe, irrigação com $\mathrm{NaOCl}$ a 2,5\% e medicação com pasta de hidróxido de cálcio por 7 a 10 dias. Amostras bacteriológicas foram colhidas antes do preparo e imediatamente antes da obturação e examinadas quanto à contagem total de bactérias pela reação em cadeia da polimerase em tempo real quantitativa (qPCR). Os pacientes foram acompanhados e o resultado do tratamento foi avaliado por critérios clínicos e radiográficos (índice periapical). Os casos com lesões que diminuiram mas não desapareceram foram classificados como sucesso em um critério leniente ou fracasso em um critério rígido. Quarenta e sete pacientes estavam disponíveis para avaliação bacteriológica e de 
resultados. Bactérias foram detectadas em todas as amostras iniciais desses casos e foram significativamente reduzidas após o tratamento nos dois grupos $(p<0,001)$. Nos grupos Reciproc e BioRaCe, os canais radiculares apresentaram resultados negativos na qPCR em 7/25 (28\%) e 11/22 (50\%) casos antes da obturação, respectivamente $(p>0,05)$. A redução bacteriana foi semelhante entre os grupos $(p>0,05)$. 0 periodo médio (mediana) de acompanhamento foi de 20,5 $(18,5)$ meses para BioRaCe e 17,4 (18) meses para Reciproc $(p>0,05)$. No grupo BioRaCe, a taxa de sucesso foi de $95,5 \%$ e $77 \%$ nos critérios leniente e rígido, respectivamente. No grupo Reciproc, os valores correspondentes foram $88 \%$ e $76 \%$. As diferenças no resultado não foram estatisticamente significativas $(p>0,05)$. Nenhum caso de doença pós-tratamento mostrou resultados negativos de qPCR para bactérias. Foi observada uma diferença $>1 \log 10$ nas contagens bacterianas entre os casos curados e doentes. 0 tratamento do canal radicular de dentes com lesão perirradicular utilizando um sistema de instrumento único ou múltiplos no preparo, associado à irrigação com $\mathrm{NaOCl}$ e medicação entre consultas com hidróxido de cálcio, mostrou eficácia antibacteriana e taxa de sucesso semelhantes.

\section{Acknowledgements}

This study was supported by grants from Fundação Carlos Chagas Filho de Amparo à Pesquisa do Estado do Rio de Janeiro (FAPERJ) and Conselho Nacional de Desenvolvimento Científico e Tecnológico (CNPq), Brazilian Governmental Institutions.

\section{References}

1. Ørstavik D, Pitt Ford TR. Apical periodontitis: microbial infection and host responses. In: Ørstavik D, Pitt Ford TR, eds. Essential endodontology. 2nd ed. Oxford, UK: Blackwell Munksgaard Ltd 2008:1-9.

2. Siqueira JF Jr, Rôças IN. Clinical implications and microbiology of bacterial persistence after treatment procedures. J Endod 2008;34:1291-1301.

3. Yared G. Canal preparation using only one Ni-Ti rotary instrument: preliminary observations. Int Endod J 2008;41:339-344.

4. Marinho AC, Martinho FC, Gonçalves LM, Rabang HR, Gomes BP. Does the Reciproc file remove root canal bacteria and endotoxins as effectively as multifile rotary systems? Int Endod J 2015;48:542-548.

5. Machado ME, Nabeshima CK, Leonardo MF, Reis FA, Britto ML, Cai S. Influence of reciprocating single-file and rotary instrumentation on bacterial reduction on infected root canals. Int Endod J 2013;46:10831087.

6. Siqueira JF Jr, Alves FR, Versiani MA, Rôças IN, Almeida BM, Neves $M A$, et al. Correlative bacteriologic and micro-computed tomographic analysis of mandibular molar mesial canals prepared by self-adjusting file, Reciproc, and Twisted File systems. J Endod 2013;39:1044-1050.

7. Alves FR, Rôças IN, Almeida BM, Neves MA, Zoffoli J, Siqueira JF Jr. Quantitative molecular and culture analyses of bacterial elimination in oval-shaped root canals by a single-file instrumentation technique. Int Endod J 2012;45:871-877.

8. Nakamura VC, Candeiro GT, Cai S, Gavini G. Ex vivo evaluation of three instrumentation techniques on $\mathrm{E}$. faecalis biofilm within oval shaped root canals. Braz Oral Res 2015;29.

9. Martinho FC, Freitas LF, Nascimento GG, Fernandes AM, Leite FR, Gomes AP et al. Endodontic retreatment: clinical comparison of reciprocating systems versus rotary system in disinfecting root canals. Clin Oral Investig 2015;19:1411-1417.

10. Martinho FC, Gomes AP, Fernandes AM, Ferreira NS, Endo MS, Freitas
$L F$, et al. Clinical comparison of the effectiveness of single-file reciprocating systems and rotary systems for removal of endotoxins and cultivable bacteria from primarily infected root canals. J Endod 2014;40:625-629.

11. Neves MA, Provenzano JC, Rôças IN, Siqueira JF, Jr. Clinical antibacterial effectiveness of root canal preparation with reciprocating singleinstrument or continuously rotating multi-instrument systems. J Endod 2016;42:25-29.

12. Cavalli D, Toia CC, Flores Orozco El, Khoury RD, Cardoso FGDR, Alves $M C$, et al. Effectiveness in the removal of endotoxins and microbiological profile in primary endodontic infections using 3 different instrumentation systems: a randomized clinical study. J Endod 2017:43:1237-1245.

13. Ørstavik D. Time-course and risk analyses of the development and healing of chronic apical periodontitis in man. Int Endod J 1996;29:150-155.

14. Zandi H, Petronijevic N, Mdala I, Kristoffersen AK, Enersen M, Rôças IN, et al. Outcome of endodontic retreatment using 2 root canal irrigants and influence of infection on healing as determined by a molecular method: a randomized clinical trial. J Endod 2019;45:1089-1098.

15. Siqueira JF, Jr, Rôças IN. Exploiting molecular methods to explore endodontic infections: Part 1-current molecular technologies for microbiological diagnosis. J Endod 2005;31:411-423.

16. Martin $\mathrm{FE}$, Nadkarni MA, Jacques NA, Hunter N. Quantitative microbiological study of human carious dentine by culture and realtime PCR: association of anaerobes with histopathological changes in chronic pulpitis. J Clin Microbiol 2002;40:1698-1704.

17. Rôças IN, Siqueira JF Jr. Characterization of microbiota of root canal-treated teeth with posttreatment disease. J Clin Microbiol 2012;50:1721-1724

18. Ørstavik D, Kerekes K, Eriksen HM. The periapical index: a scoring system for radiographic assessment of apical periodontitis. Endod Dent Traumatol 1986;2:20-34.

19. Zandi H, Rodrigues RC, Kristoffersen AK, Enersen M, Mdala I, Ørstavik D, et al. Antibacterial effectiveness of 2 root canal irrigants in root-filled teeth with infection: a randomized clinical trial. J Endod 2016;42:13071313.

20. Rodrigues RCV, Zandi H, Kristoffersen AK, Enersen M, Mdala I, Ørstavik $D$, et al. Influence of the apical preparation size and the irrigant type on bacterial reduction in root canal-treated teeth with apical periodontitis. J Endod 2017;43:1058-1063.

21. Siqueira JF, Jr, Lima KC, Magalhaes FA, Lopes HP, de Uzeda M. Mechanical reduction of the bacterial population in the root canal by three instrumentation techniques. J Endod 1999;25:332-335.

22. McGurkin-Smith R, Trope M, Caplan D, Sigurdsson A. Reduction of intracanal bacteria using GT rotary instrumentation, $5.25 \% \mathrm{NaOCl}$ EDTA, and $\mathrm{Ca}(\mathrm{OH}) 2$. J Endod 2005;31:359-363.

23. Friedman S. Expected outcomes in the prevention and treatment of apical periodontitis. In: Ørstavik D, Pitt Ford T, eds. Essential endodontology. Oxford, UK: Blackwell Munksgaard Ltd 2008:408-469.

24. Siqueira JF Jr, Rôças IN. Uncultivated phylotypes and newly named species associated with primary and persistent endodontic infections. J Clin Microbiol 2005;43:3314-3319.

25. Ørstavik D, Kerekes K, Eriksen HM. Clinical performance of three endodontic sealers. Endod Dent Traumatol 1987;3:178-186.

Received February 14, 2020 Accepted September 25, 2020 